Article

\title{
The Dual Processing of Donation Size in Cause-Related Marketing (CRM): The Moderating Roles of Construal Level and Emoticons
}

\author{
Dongho Yoo ${ }^{1}$, Jung-Ae Kim ${ }^{2}$ and Sun-Jae Doh ${ }^{2, *}$ (i) \\ 1 School of Business Administration, Chung-Ang University, 84, Heukseok-ro, Dongjak-gu, \\ Seoul 06974, Korea; toocalm@cau.ac.kr \\ 2 Da Vinci College of General Education, Chung-Ang University, 84, Heukseok-ro, Dongjak-gu, \\ Seoul 06974, Korea; jakim1213@cau.ac.kr \\ * Correspondence: realsun@cau.ac.kr; Tel.: +82-02-820-6930
}

Received: 17 October 2018; Accepted: 14 November 2018; Published: 15 November 2018

\begin{abstract}
Donation size is known to be one of the factors that determines the success of cause-related marketing (CRM), which is the most practical form of corporate social responsibility (CSR). Although various studies have investigated the influence of donation size on CRM, they have not shown clear results. In addition, no research has examined the mechanism of how consumers process donation-size information. In this study, we examined the effect of donation size on consumer responses, focusing on the differences in perceived benefits and perceived monetary sacrifice according to the construal level. Furthermore, we investigated the role of emoticons as a way to increase the intention to participate in CRM by lowering the consumers' perceptions of monetary sacrifice. Study 1 showed that for consumers with a higher construal level who perceive donation size as benefits, donation size had positive effects on consumer responses, whereas for those with a lower construal level who perceive donation size as monetary sacrifice, it had negative effects on their responses. Study 2 showed that emoticons attenuated the interaction effect of donation size and construal level. Finally, the implications of this study are discussed.
\end{abstract}

Keywords: cause-related marketing; donation size; construal level; perceived benefits; perceived monetary sacrifice; emoticons

\section{Introduction}

As interest in corporate social responsibility (CSR), considered to be an indispensable part of corporate sustainability-related activities, has increased [1], cause-related marketing (CRM), the most practical form of CSR [2] has also increased [3]. In fact, the amount of CRM spending worldwide has increased from $\$ 55.3$ billion in 2014 to $\$ 62.7$ billion in 2017, up by more than $4 \%$ annually [4]. Because of the increased interest in and spending on CRM, there is also growing academic interest in the topic. Although previous studies have suggested that CRM may lead consumers to doubt corporate motivation, it has shown generally positive effects on product attitudes [5], purchase intentions, and company evaluations [6,7]. Cause-related marketing is a useful marketing strategy for corporations [3].

The most important characteristic of CRM is that consumers' purchasing behavior is directly related to corporate donation [8]. In other words, consumers can donate a certain amount of money, which a company has already incorporated into the price of its products or services, by their purchasing behavior. The donation size in the price is the factor that can be directly controlled and designed by managers [9]. Companies are implementing CRM by setting various sizes of donations within the 
price. For example, Procter \& Gamble (P\&G, Cincinnati, OH, USA) donated $1 \%$ of the price to UNICEF for all promotional packages sold, while Tommy Hilfiger donated $50 \%$ of the price to Breast Health International. However, the results of previous studies on donation size are unclear [9]. Some studies have shown that donation size has a positive impact on CRM success [10], while other studies have either shown negative effects [11] or no significant effect [12]. Thus, previous studies do not provide clear implications for the size of a corporation's donation. In addition, no study has examined the mechanism of how consumers interpret information about donation size, although donation size may affect consumers' perceptions or judgments $[8,13]$. In this study, we investigate the effect of donation size and its mechanism by focusing on the perceived benefits and monetary sacrifice of consumers. According to previous studies, consumers at higher construal levels focus on the benefits or values of behaviors or objects, while those at lower construal levels focus on the acquisition or feasibility of value $[14,15]$. Based on these findings, this study investigates the effect of donation size on consumer responses such as product attitudes and intentions to participate in CRM, focusing on the difference of perceived benefits and monetary sacrifice according to construal level.

Furthermore, we examine ways to positively change consumers' responses by lowering their perceptions of monetary sacrifice. In particular, based on previous studies showing that the fulfillment of the need for social relationships reduces the importance of money and spending pain [16,17], this study analyzes the influence of emoticons, which positively influence satisfaction of social relationship needs. The results of this study are expected to provide effective and valuable implications for companies regarding the use of emoticons as a marketing strategy that can be effortlessly utilized by company managers while communicating with consumers.

The aims of this study are as follows. Previous studies that examined the influence of donation size did not provide clear results, and there was little interest in the mechanism of the influence of donation size. Therefore, we investigate the difference in consumer responses on donation size according to construal level and analyze the mediating role of perceived benefits and monetary sacrifice. Furthermore, this study examines the role of emoticons as a communication method that can lead to consumers' positive responses by lowering consumers' perceptions of monetary sacrifice. In other words, based on the relationship between construal level and perceived benefits/monetary sacrifice, we examine not only the mechanism of donation size effect that previous studies have not examined, but also suggest ways to increase consumer participation in CRM following this mechanism. This is expected to help expand the research on CRM and donation.

\subsection{Cause-Related Marketing}

Corporate social responsibility is defined as companies' obligations to society [18]. Previous studies have shown the positive impacts of CSR on attitudinal loyalty, purchase intentions (e.g., [1]), and financial performance of the company (e.g., $[19,20])$. Likewise, marketers' interest in CSR activities has increased. Companies are now using CSR activities as an effective public relation (PR) tools to attract consumers' attention, and they are undertaking various types of CSR activities (e.g., philanthropy, sponsorship, and CRM). In this study, we focused on CRM, the most practical form of CSR [2], among various CSR strategies.

Cause-related marketing is defined as "the process of formulating and implementing marketing activities that are characterized by organizational and individual objectives" ([21], p. 60). It is a marketing strategy in which a company donates a portion of the price of a specific product to a social cause [2]. Consumers have positive attitudes and intentions to participate in CRM [22] because they can make donation decisions with relatively little money and without additional transactional costs $[23,24]$. They also believe that participating in CRM will not only meet their personal needs but also contribute to a better society [25]. The feeling of warmth that consumers gain from helping others makes them respond positively to CRM [26]. Their favorable response to CRM has positive impacts on donation intentions, choice, purchase intentions $[9,10,27-31]$ as well as on attitudes toward the corporate [32], brand [33], product [34], and activity agendas [35]. 
Previous studies have shown that several factors such as company [36], product [30], consumer [37], cause [38], non-profit organization (NPO; [39]), the fit between each factor [40], and donation size or donation framing [9] affect the success of CRM. For example, Strahilevitz and Myers [30] reported that the impacts of CRM incentives are more positive in hedonic products than in utilitarian products. And Zdravkovic, Magnusson, and Stanley [40] found that brand-cause fit has positive effects on consumer attitudes toward the CRM and the brand.

\subsection{Donation Size}

Donation size is one of the most important elements in the success of CRM [9]. Donation size differs from other factors in that it can be directly controlled by the manager [9] and is directly related to the magnitude of the return to society $[25,41]$.

The amount of money donated by a company through CRM affects consumers' attitudes and their participation intentions. However, the results of previous studies have not shown clear effects of donation size. Previous studies showing the positive effects of donation size indicate that as the donation size increases, consumers become more aware that donations help others through the purchase and generate positive feeling of warm glow [22,34,42]. Similarly, Krishna [43] confirmed that consumers consider purchasing CRM products as charitable activities. Donation size also serves as a signal to consumers to determine the effect of CRM [44]. In other words, consumers perceive that CRM is more effective when the company presents larger donation size. If the donation size is small, consumers may doubt the authenticity of CRM activities. Dahl and Lavack [22] point out that donation size should be set higher because there may be a perception that firms strategically use NPOs when the amount of donation is small. And Hajjat [44] argued that low donation size makes consumers feel frustrated, leading to negative attitudes and purchase intentions.

However, previous studies that indicate the negative effects of donation size mainly focus on consumer perceptions of monetary sacrifice. That is, after consumers notice information about donation size, they experience both positive feelings from helping others and negative feelings from paying more [11]. Then, if consumers are more aware of monetary sacrifice, their intentions to participate in CRM are lowered. According to the results of Chang and Lee [45] on consumer preferences for donations and price discounts of the same amount, consumers preferred donations rather than price discounts if the amounts of donations or discount were small, while consumers preferred price discounts rather than donations if the amounts were large. In other words, the perceived monetary sacrifice of consumers is greater when the donation size is larger than when it is smaller, and therefore, self-interest is more important to consumers than donation motivation. Likewise, Müller et al. [9] also found that perceptions of monetary sacrifice affected the effect of donation size. Specifically, donation size positively influenced brand image when donation was in a non-monetary frame, but donation size negatively affected brand image in a monetary frame. That is, donation size negatively affects consumer responses when they have monetary concerns.

In summary, the results of previous studies show that donation size may have either a positive impact on consumers' participation intentions in CRM due to perceived warmth, or a negative impact on participation intentions due to perceived monetary sacrifice.

\subsection{Construal Level Theory}

According to construal level theory, people construe the same objects or events in different ways depending on their construal level [46,47]. Specifically, at higher construal level, people interpret the objects or events with a more abstract mindset. Higher construal level allows consumers to more focus on desirability, which means the value of the behavior's end state. However, at lower construal level, people interpret objects or events with a more concrete mindset. Lower construal level allows consumers to more focus on feasibility, which implies the means used to reach the end state [48-50].

Previous studies have suggested that construal level is related to psychological distance such as temporal, social, spatial, and hypothetical distance [15,51]. According to them, objects that are more 
psychologically distant are construed at higher levels, while psychologically more near objects are construed at lower levels. However, other studies showed that construal levels differ by psychological distance as well as by other variables such as mood [52], self-construal [53], and the luxury level [54].

Regarding the donation size in CRM, this study focuses on differential emphasis of consumers on the desirability and feasibility aspects depending on their construal level. As mentioned earlier, higher construal level increases the weight of desirability more than the feasibility. Thus, consumers in high-level construal judge the attractiveness of products based on the value and benefits of the products, while consumers in low-level construal judge the attractiveness of products based on the means and ease of acquisition of the products. In this regard, Trope et al. [15] argued that while the benefits offered by the product are related to high-level construal, the costs associated with the purchase and use of the product are related to low-level construal. Bornemann and Homburg [14] showed that price information processing of consumers change according to their construal level. Specifically, consumers engaging in higher construal level, focusing on the benefits of products, interpret price information as a cue for quality, while those engaging in lower construal level, focusing on the way to acquire products, interpret price information as a monetary sacrifice. Therefore, participants engaging in high-level construal evaluated the product more positively as the price level increased, because high price implies good product quality, while those engaging in low-level construal evaluated the product more negatively as the price level increased, because high price implies that the product is difficult to obtain.

Concerning CRM, we predict that consumers' processing of donation size information will vary depending on their construal level. It is expected that consumers engaged in high-level construal will evaluate CRM more positively when the donation size is larger than when it is smaller because they focus on the benefits of donation, where large donation size implies more benefits of donation. However, it is expected that consumers engaged in low-level construal will evaluate CRM more negatively when the donation size is larger than when it is smaller because they focus on monetary sacrifice of donation, where large donation size implies more monetary sacrifice of donation. Hence, the following hypotheses were proposed.

Hypothesis 1 (H1). Perceived benefits for a large donation size compared to a small donation size will be higher when consumers engage in a higher construal level than when they engage in a lower construal level.

Hypothesis 2 (H2). Perceived monetary sacrifice for a large donation size compared to a small donation size will be higher when consumers engage in a lower construal level than when they engage in a higher construal level.

Hypothesis 3 (H3). Consumers' (a) product attitudes and (b) participation intentions for a large donation size compared to a small donation size will be more favorable when consumers engage in a higher construal level than when they engage in a lower construal level.

Hypothesis 4 (H4). The effects of donation size and construal level on consumer responses (product attitudes, participation intentions) will be mediated by perceived benefits and perceived monetary sacrifice.

\subsection{Emoticons}

Emoticons are defined descriptions of a facial expression using text (e.g., : ), :( ) or pictures (e.g., $\odot$ ) and serve as non-verbal cues to convey emotions in the context of digital communication [55-58]. Previous studies have found that emoticons positively affect consumers' understanding of messages $[59,60]$, acceptance of negative feedback [61], service satisfaction, and behavioral intentions [57].

In particular, $\mathrm{Li}$ et al. [57] found that although emoticons negatively impact consumers' perceptions of competence, which involve perceptions of skillfulness, capability, and efficacy, they also increase perceptions of warmth, which involve perceptions of sociability, friendliness, and helpfulness. In other words, corporate communication strategies using emoticons have a positive impact on the 
perceptions of warmth, although they may have a negative impact on the perceptions of competence of brands or products. Furthermore, perceptions of warmth enhance consumers' perceived belonging and satisfy their desire for social relationships $[62,63]$. This study predicts that these emoticons, by enhancing the perception of warmth and satisfying the desire for social relationships, will attenuate the effects of donation size and construal level on consumer responses.

Previous studies have suggested that the desire for social relationships is closely related to the desire for money [17]. Specifically, social relationships and money are interchangeable relationships in which the desire for one is reduced when one is satisfied. The importance of money reduces the importance of social relationships [64,65], but conversely, the importance of social relationships reduces the importance of money. For example, Chaplin and John [66] found that children who received positive feedback from their peers had a lower level of materialism than those who did not. This is because positive feedback, like praise for appearance, reduces the children's perceptions of the importance of money. Thus, people tend to pursue goals for money or other material things when the basic desire for social relationships is not met, and they tend to naturally think of money as less important when the desire for social relationships is met [67]. Likewise, Lasaleta et al. [16] showed that the desire for social relationships fulfilled by nostalgia lowers the consumers' perceived importance of money. Xu et al.'s [17] experiments, which investigated the relationship between social support and spending pain, also showed the same results. Specifically, social support decreased spending pain by lowering the perceived importance of money. These results of previous research suggest that when consumers' desire for social relationships is met, they regard cost-related aspects as less important. Therefore, in this study, it is expected that the use of emoticons that can satisfy the desire for social relationships will reduce the consumers' perceptions of cost related to donation size in CRM. Put differently, when emoticons are presented, donation size and construal level have no significant influence on the consumer responses.

Hypothesis 5 (H5). The interaction effects of donation size and construal level on (a) product attitudes and (b) participation intentions will be attenuated when emoticons are included in a CRM message.

\section{Study 1}

\subsection{Materials and Methods}

\subsubsection{Data Collection and Sample}

Study 1 investigated the effects of donation size and construal level on consumers' product attitudes and CRM participation intentions. Figure 1 presents the framework for our study. Participants of Study 1 were Americans recruited from Amazon Mechanical Turk (MTurk). Mechanical Turk is a useful tool that provides a way to easily recruit many subjects for online research. Previous research shows that MTurk participants are more diverse than the traditional college samples and are more demographically diverse than typical Internet samples [68,69]. The survey of Study 1 was conducted between 2 August 2018 and 9 August 2018. We used SPSS version 21.0 to analyze our data.

Study 1 had a 2 (donation size: large vs. small) $\times 2$ (construal level: high vs. low) between-subjects design. Eighty-one Americans from Amazon MTurk were recruited in Study 1 in exchange for monetary compensation. They were randomly assigned to one of the four conditions. The sample size of each condition was 20-21. There were no responses excluded from the analysis. Although the sample size was small, it is sufficient for the analysis methods used in this study [70]. The sample size issue is mitigated because the size exceeds the standard quantity (15-20 participants per independent variable) [71]. Of them, 49.4 percent $(n=40)$ were men $(\mathrm{M}=36.84, \mathrm{SD}=13.51$, range of age $=21-75)$ (Table 1). 


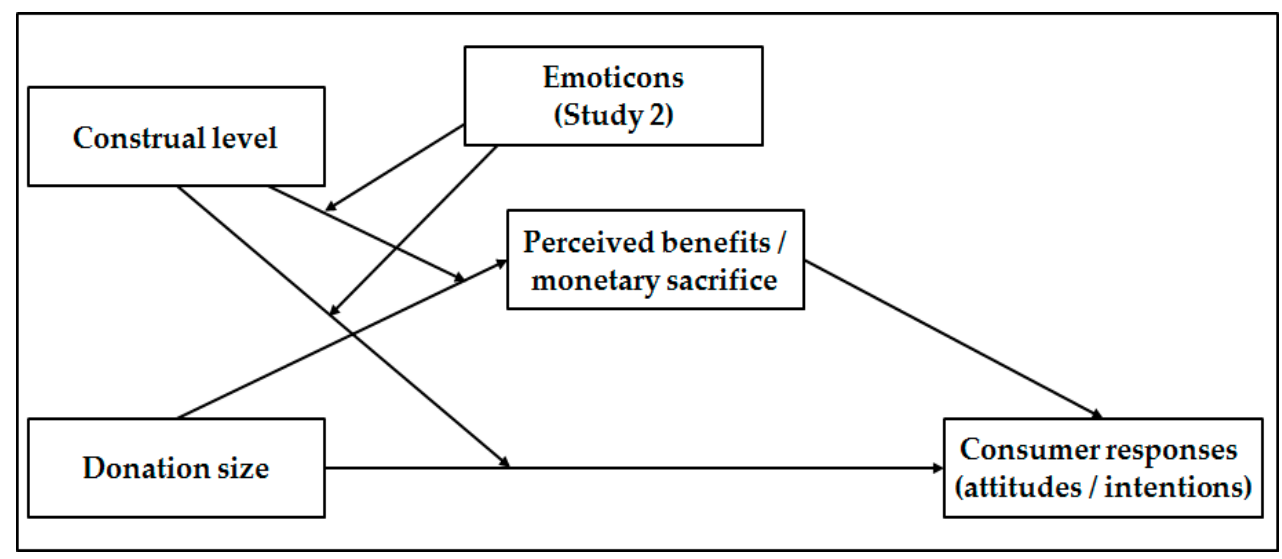

Figure 1. Conceptual model.

Table 1. Characteristics of the sample (Study 1).

\begin{tabular}{lccc}
\hline \multirow{2}{*}{ Gender } & Characteristics & $\boldsymbol{N}$ & $\mathbf{\%}$ \\
\hline \multirow{4}{*}{ Age } & Male & 40 & 49.4 \\
& Female & 41 & 50.6 \\
\hline & $20-29$ & 35 & 43.2 \\
& $30-39$ & 26 & 32.1 \\
& $40-49$ & 6 & 7.4 \\
& $50-59$ & 5 & 6.2 \\
& $\geq 60$ & 9 & 11.1 \\
\hline
\end{tabular}

\subsubsection{Development of Stimuli Materials}

We selected mineral water as the product category based on previous studies [8]. Mineral water is one of the most frequently purchased product categories by consumers. Experimental stimuli were made in two versions depending on the donation size (see Appendix A). Specifically, based on the research by Folse et al. [13] and Chang [72], the small donation size and large donation size was set at $5 \%$ and $40 \%$ of the regular price, respectively.

We performed a pretest to verify that the stimuli related to donation size were appropriate. Thirty-eight participants from Amazon MTurk were recruited in the pretest. Of them, 47.4 percent $(n=18)$ were men $(\mathrm{M}=39.2, \mathrm{SD}=12.08)$. The results indicated that subjects in the large donation size condition $(\mathrm{M}=4.60)$ perceived that more money was donated to others than in the small donation size condition $(\mathrm{M}=2.89 ; t=3.436, p<0.01)$.

\subsubsection{Methods}

Subjects first performed tasks related to the construal level. The construal level was manipulated following Fujita, Trope, Liberman, and Levin-Sagi [73] and Wang, Hong, and Zhou [74]. Specifically, all participants received a list of 15 nouns (e.g., pasta). Participants from the higher construal level were asked to write superordinate category labels (e.g., food), whereas those from the lower construal level were asked to write subordinate exemplars (e.g., carbonara). Afterward, they responded to the manipulation check items of construal level. Their construal level was measured by the Behavioral Identification Form (BIF; [75]).

After the construal-level manipulation task, participants received a scenario, including brief information about the mineral water manufacturer and about the company's current CRM initiative, and a questionnaire. The participants then responded to the items of perceived benefits, perceived monetary sacrifice, product attitudes, CRM participation intentions, and the manipulation check items for donation size. Finally, they responded to the items related to demographics. 


\subsubsection{Measures}

Construal level was measured using the BIF [75] and a 19-item questionnaire. For each question, participants were asked to choose an option that seems to adequately represent the presented action (e.g., eating). One option was describing the action abstractly (e.g., getting nutrition) and the other was describing concretely (e.g., chewing and swallowing). We coded 1 when the participants chose the options described abstractly and 0 when they chose the options described concretely. The sum of the responses was used as a BIF score. The BIF scores ranged from 0-19 points and higher BIF scores indicated that participants had a higher construal level.

Donation size was measured with two items by Koschate-Fischer et al. [8]. Perceived benefits were measured with three items that were adopted from Andrews et al. [26] and Green and Peloza [76]. Perceived monetary sacrifice was measured by modifying two of the items used by Bornemann and Homburg [14] and Suri and Monroe [77]. Product attitudes was measured with four items by Mitchell and Olson (1981), and participation intentions were measured with four items used by Grau and Folse [41].

Cronbach's alpha of each scale was higher than 0.8 (see Table 2).

Table 2. Results of reliability analysis.

\begin{tabular}{|c|c|c|}
\hline Variables & Items & Cronbach's Alpha \\
\hline \multirow{2}{*}{ donation size } & $\begin{array}{l}\text { [5\%/40\%] Donation of price in this situation a low vs. } \\
\text { high amount. }\end{array}$ & \multirow{2}{*}{$\begin{array}{c}0.869 \\
(0.901)\end{array}$} \\
\hline & $\begin{array}{l}\text { [5\%/40\%] Donation in this situation a below average vs. above } \\
\text { average amount. }\end{array}$ & \\
\hline \multirow{3}{*}{ perceived benefits } & $\begin{array}{l}\text { I derive benefit from supporting good causes by purchasing the } \\
\text { advertised product. }\end{array}$ & \multirow{3}{*}{$\begin{array}{l}0.929 \\
(0.936)\end{array}$} \\
\hline & $\begin{array}{l}\text { After purchasing the advertised product I am satisfied as my } \\
\text { money helps support a good cause. }\end{array}$ & \\
\hline & I like that the company uses my money to support a good cause. & \\
\hline \multirow{2}{*}{$\begin{array}{l}\text { perceived monetary } \\
\text { sacrifice }\end{array}$} & $\begin{array}{l}\text { I think the price of the advertised product will be very high due } \\
\text { to the donation size. }\end{array}$ & \multirow{2}{*}{$\begin{array}{c}0.890 \\
(0.872)\end{array}$} \\
\hline & $\begin{array}{l}\text { I think the advertised product will be very expensive due to the } \\
\text { donation size. }\end{array}$ & \\
\hline product attitudes & $\begin{array}{l}\text { My attitude toward this product is good. } \\
\text { My attitude toward this product is likeable. } \\
\text { My attitude toward this product is favorable. } \\
\text { My attitude toward this product is positive. }\end{array}$ & $\begin{array}{l}0.954 \\
(0.963)\end{array}$ \\
\hline \multirow{4}{*}{$\begin{array}{l}\text { participation } \\
\text { intentions }\end{array}$} & I think this CRM campaign is a good idea. & \multirow{4}{*}{$\begin{array}{c}0.952 \\
(0.930)\end{array}$} \\
\hline & I would be willing to participate in this CRM campaign. & \\
\hline & $\begin{array}{l}\text { I would consider purchasing this product in order to provide } \\
\text { help to the cause. }\end{array}$ & \\
\hline & $\begin{array}{l}\text { It is likely that I would contribute to this cause by getting } \\
\text { involved in this CRM campaign. }\end{array}$ & \\
\hline
\end{tabular}

Note: The numbers in parentheses represent the results of Study 2. CRM = cause-related marketing.

\subsection{Results}

\subsubsection{Manipulation Check}

The ANOVA results for BIF scores revealed only the main effect of construal level $(F=4.329$, $p<0.05)$, showing that participants primed with a higher construal level $(\mathrm{M}=13.93)$ have a higher construal level than those primed with a lower construal level $(M=12.15)$. Furthermore, the ANOVA results for the donation size revealed only the main effect of the donation size $(F=15.533, p<0.001)$, 
showing that participants perceived that the donation size was larger at $40 \%(M=5.58)$ than at $5 \%$ $(\mathrm{M}=4.39)$. Therefore, the manipulations of construal level and donation size were supported.

\subsubsection{Perceived Benefits}

The ANOVA results for perceived benefits showed that the main effects of construal level and donation size were not significant (all, $p>0.1$ ). However, the two-way interaction effect between construal level and donation size was significant $(F=4.037, p<0.05)$. The contrast analysis showed that participants primed with higher construal level were more likely to perceive the benefits of CRM in the large donation size condition $(M=5.75)$ than in the small donation size condition $(M=4.40$; $F=6.629, p<0.05)$. However, among those primed with a lower construal level, there were no significant differences in perceived benefits according to donation size $(F=0.064, p>0.1)$ (see Table 3 and Figure 2). This means that, unlike participants primed with a lower construal level, those primed with a higher construal level perceive more benefits of CRM as the donation size increased. Therefore, H1 was supported.

Table 3. Study 1 Results: means and standard deviations.

\begin{tabular}{cccccc}
\hline $\begin{array}{c}\text { Construal } \\
\text { Level }\end{array}$ & $\begin{array}{c}\text { Donation } \\
\text { Size }\end{array}$ & $\begin{array}{c}\text { Perceived } \\
\text { Benefits }\end{array}$ & $\begin{array}{c}\text { Perceived Monetary } \\
\text { Sacrifice }\end{array}$ & $\begin{array}{c}\text { Product } \\
\text { Attitudes }\end{array}$ & $\begin{array}{c}\text { Participation } \\
\text { Intentions }\end{array}$ \\
\hline \multirow{2}{*}{ High } & Small & $4.40(1.58)$ & $4.75(1.52)$ & $4.89(1.19)$ & $4.69(1.12)$ \\
& Large & $5.75(0.75)$ & $4.45(1.61)$ & $5.80(0.89)$ & $5.59(1.03)$ \\
\hline \multirow{2}{*}{ Low } & Small & $4.75(1.91)$ & $3.93(1.52)$ & $5.10(1.19)$ & $5.25(1.49)$ \\
& Large & $4.62(2.06)$ & $5.33(1.75)$ & $4.26(2.12)$ & $4.33(1.95)$ \\
\hline
\end{tabular}

Note: The numbers in parentheses represent standard deviations.

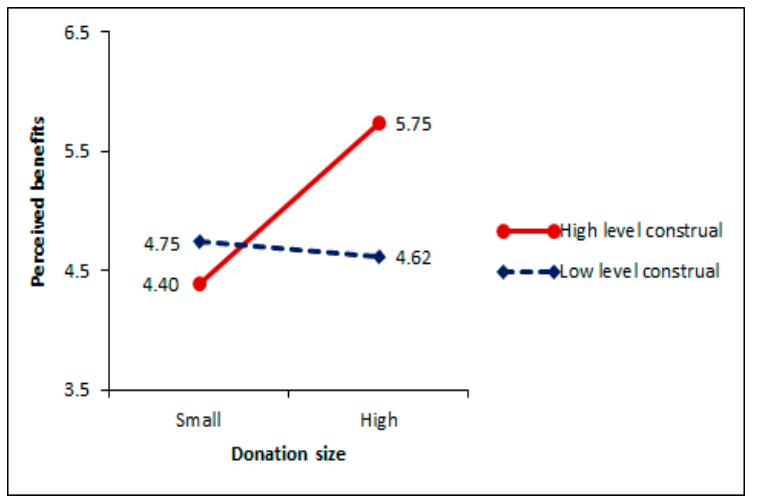

(a)

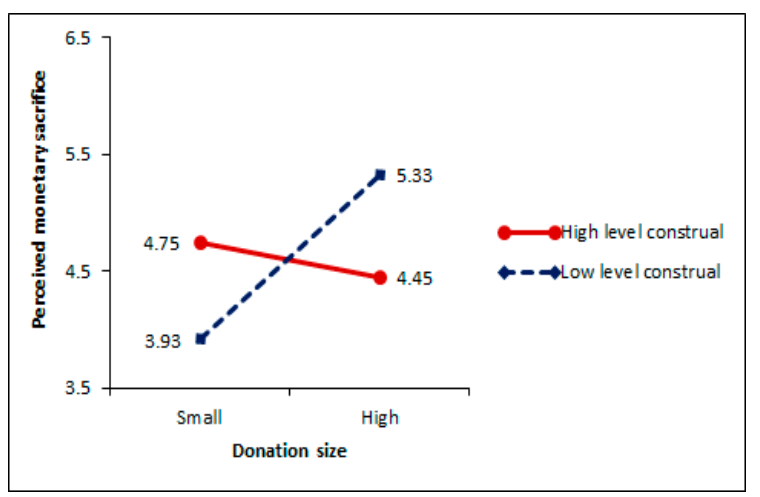

(b)

Figure 2. Interaction effects on (a) perceived benefits and (b) perceived monetary sacrifice.

\subsubsection{Perceived Monetary Sacrifice}

The ANOVA results for perceived monetary sacrifice showed that the main effects of construal level and donation size were not significant (all, $p>0.1$ ). However, the two-way interaction effect was significant $(F=5.831, p<0.05)$. It was confirmed through a contrast analysis that among participants primed with a higher construal level, there were no significant differences in perceived monetary sacrifice according to donation size $(F=0.355, p>0.1)$. However, those primed with a lower construal level were more likely to perceive monetary sacrifice of CRM in the large donation size condition $(\mathrm{M}=5.33)$ than in the small donation size condition $(\mathrm{M}=3.93 ; F=8.023, p<0.01)$ (see Table 3 and Figure 2). This means that, unlike participants primed with a higher construal level, those primed with a lower construal level perceive more monetary sacrifice of CRM as the donation size increased. Therefore, $\mathrm{H} 2$ was supported. 


\subsubsection{Product Attitudes}

The ANOVA results for product attitudes revealed the main effect of construal level $(F=4.310$, $p<0.05)$, showing that participants primed with a higher construal level $(M=5.34)$ had more positive attitudes toward the product than those primed with a lower construal level $(\mathrm{M}=4.67)$. The main effect of donation size was not significant $(F=0.014, p>0.1)$. More importantly, the two-way interaction effect was significant $(F=7.516 p<0.01)$. The contrast analysis showed that participants primed with a higher construal level had more positive product attitudes in the large donation size condition $(\mathrm{M}=5.80)$ than in the small donation condition $(\mathrm{M}=4.89 ; F=4.036, p<0.05)$. However, those primed with a lower construal level had more positive attitudes in the small donation size condition $(\mathrm{M}=5.10)$ than in the large donation size condition ( $\mathrm{M}=4.26 ; F=3.487, p=0.066)$ (see Table 3 and Figure 3). Therefore, H3a was also supported.

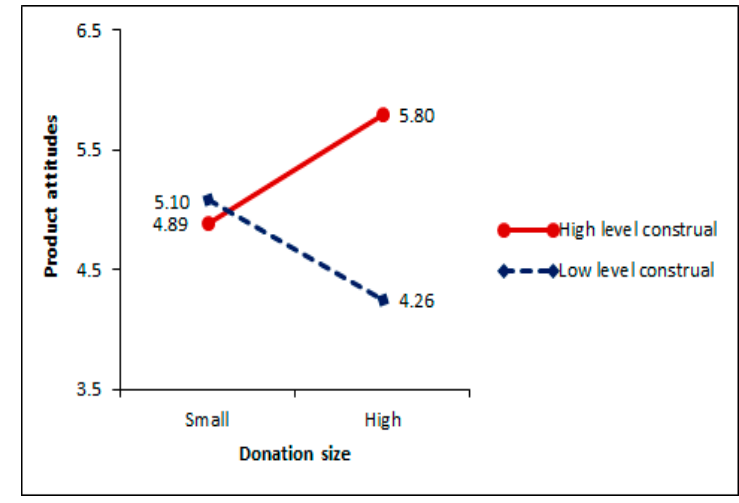

(a)

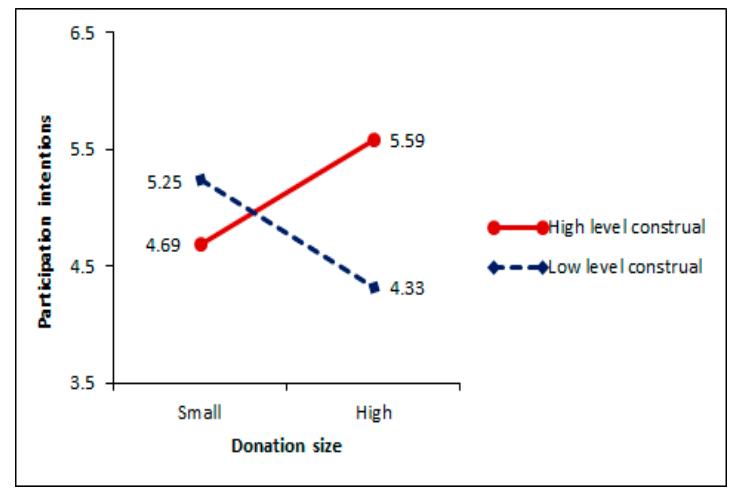

(b)

Figure 3. Interaction effects on (a) product attitudes and (b) participation intentions.

\subsubsection{Participation Intentions}

The ANOVA results for participation intentions showed that the main effects of construal level and donation size were not significant (all, $p>0.1$ ). As predicted, however, the two-way interaction effect was significant $(F=7.929 p<0.01)$. The contrast analysis showed that participants primed with a higher construal level had more positive CRM participation intentions in the large donation size condition ( $\mathrm{M}=5.59)$ than in the small donation size condition $(\mathrm{M}=4.69 ; F=3.846, p=0.053)$. However, those primed with a lower construal level had more positive participation intentions toward the CRM in the small donation size condition $(M=5.25)$ than in the large donation size condition $(M=4.33$; $F=4.087, p<0.05$ ) (see Table 3 and Figure 3). Therefore, H3b was also supported.

\subsubsection{Mediation Analysis}

To clarify the mechanism of this study, we performed mediation analyses by model 6 of the PROCESS macro [78]. A bootstrapping analysis with 10,000 resamples was conducted [79] (see Table 4).

First, when participants were primed with a higher construal level, the indirect effect (donation size $\rightarrow$ perceived benefits $\rightarrow$ product attitudes $\rightarrow$ participation intentions) was significant (indirect effect $=36,95 \%$ CI: 0.08 0.99), indicating mediation. However, when mediators were set to perceived monetary sacrifice and product attitudes, the indirect effect (donation size $\rightarrow$ perceived monetary sacrifice $\rightarrow$ product attitudes $\rightarrow$ participation intentions) was found to be non-significant (indirect effect $=-0.03,95 \%$ CI: $-0.22 \sim 0.04)$, indicating no mediation. This implies that as the size of the donation increases, consumers at a higher construal level were more likely to perceive benefits rather than monetary sacrifice, leading to positive product attitudes and CRM participation intentions.

However, among participants primed with a lower construal level, when mediators were set to perceived benefits and product attitudes, the indirect effect (donation size $\rightarrow$ perceived benefits $\rightarrow$ product attitudes $\rightarrow$ participation intentions) was found to be insignificant (indirect effect $=-0.04$, 
95\% CI: $-0.49 \sim 0.31$ ), indicating no mediation. However, when mediators were set to perceived monetary sacrifice and product attitudes, the indirect effect (donation size $\rightarrow$ perceived monetary sacrifice $\rightarrow$ product attitudes $\rightarrow$ participation intentions) was significant (indirect effect $=-0.34,95 \% \mathrm{CI}$ : $-1.09 \sim-0.01)$, indicating mediation. This implies that as the donation size increases, consumers at a lower construal level are more likely to perceive monetary sacrifice rather than benefits, leading to negative product attitudes and CRM participation intentions. These results imply that Hypothesis 4 is supported.

Table 4. Mediation analysis results (Study 1).

\begin{tabular}{|c|c|c|c|c|}
\hline \multicolumn{5}{|c|}{ High-Level Construal } \\
\hline IV & MV 1 & MV 2 & DV & $95 \% \mathrm{CI}$ \\
\hline \multirow{2}{*}{$\begin{array}{l}\text { Donation } \\
\text { size }\end{array}$} & Perceived benefits & \multirow{2}{*}{$\begin{array}{l}\text { Product } \\
\text { attitudes }\end{array}$} & \multirow{2}{*}{$\begin{array}{l}\text { Participation } \\
\text { intentions }\end{array}$} & $0.08 \sim 0.99$ \\
\hline & $\begin{array}{c}\text { Perceived monetary } \\
\text { sacrifice }\end{array}$ & & & $-0.22 \sim 0.04$ \\
\hline \multicolumn{5}{|c|}{ Low-Level Construal } \\
\hline \multirow{2}{*}{$\begin{array}{l}\text { Donation } \\
\text { size }\end{array}$} & Perceived benefits & \multirow{2}{*}{$\begin{array}{l}\text { Product } \\
\text { attitudes }\end{array}$} & \multirow{2}{*}{$\begin{array}{l}\text { Participation } \\
\text { intentions }\end{array}$} & $-0.49 \sim 0.31$ \\
\hline & $\begin{array}{l}\text { Perceived monetary } \\
\text { sacrifice }\end{array}$ & & & $-1.09 \sim-0.01$ \\
\hline
\end{tabular}

Note: IV = independent variable; MV 1 = first mediate variables; MV 2 = second mediate variable; DV = dependent variable.

\section{Study 2}

In Study 2, we investigated whether the interaction effect between construal level and donation size on consumers' responses to CRM varies depending on the use of emoticons (see Figure 1). Thus, Study 2 was applied to verify Hypothesis 5. Moreover, we tried to generalize the results of Study 1 by selecting coffee instead of mineral water as an experimental stimulus.

\subsection{Materials and Methods}

Study 2 had a 2 (donation size: large vs. small) $\times 2$ (construal level: high vs. low) $\times 2$ (emoticons: yes vs. no) between-subjects design. The survey of Study 2 was conducted between 21 August 2018 and 24 August 2018. One-hundred-and-seventy-two Americans from Amazon MTurk were recruited, and they were randomly assigned to one of the eight conditions. The sample size of each condition was 20-23. There were no responses excluded from the analysis. Of them, 52.3 percent $(n=90)$ were men $(\mathrm{M}=38.00, \mathrm{SD}=12.75$, range of age $=20-75)($ Table 5$)$.

Table 5. Characteristics of the sample (Study 2).

\begin{tabular}{lccc}
\hline \multirow{2}{*}{ Gender } & Characteristics & $\boldsymbol{N}$ & $\mathbf{\%}$ \\
\hline \multirow{4}{*}{ Age } & Male & 90 & 52.3 \\
& Female & 82 & 47.7 \\
\hline & $20-29$ & 55 & 32.0 \\
& $30-39$ & 65 & 37.8 \\
& $40-49$ & 23 & 13.3 \\
& $50-59$ & 15 & 8.8 \\
& $\geq 60$ & 14 & 8.1 \\
\hline
\end{tabular}

The method was similar to Study 1. Participants first performed tasks related to construal level (manipulation and manipulation check). Participants then received a scenario, including brief information about the coffee manufacturer and about CRM that the company was currently carrying out, and a questionnaire. Experimental stimuli were made in four versions depending on the donation 
size and emoticons (see Appendix A). The donation size was set the same as in Study 1 (small size: 5\% of the regular price, large size: $40 \%$ of the regular price).

Afterwards, participants responded to the items of perceived benefits, perceived monetary sacrifice, product attitudes, CRM participation intentions, and to the manipulation check items for donation size. Finally, they responded to the items related to demographics. The scales are the same as in Study 1, and Cronbach's alpha of each scale was higher than 0.8 (see Table 2).

\subsection{Results}

\subsubsection{Manipulation Check}

The ANOVA results for BIF scores revealed only the main effect of construal level $(F=6.507$, $p<0.05)$, showing that participants primed with a higher construal level $(M=14.18)$ have a higher construal level than those primed with a lower construal level $(\mathrm{M}=12.48)$. Furthermore, the ANOVA results for the donation size revealed only the main effect of donation size $(F=54.923, p<0.001)$, showing that participants perceived that the size was larger at $40 \%(M=5.51)$ than at $5 \%(M=3.93)$. Therefore, the manipulations of construal level and donation size were successful.

\subsubsection{Perceived Benefits}

The 2 (donation size) $\times 2$ (construal level) $\times 2$ (emoticons) ANOVA results for perceived benefits revealed the main effect of donation size $(F=11.397, p<0.01)$, showing that participants were more likely to perceive benefits of CRM when the size of donation was large $(M=5.20)$ than when the size was small ( $\mathrm{M}=4.33)$. The main effects of construal level and emoticons were not significant (all, $p>0.1)$. More importantly, the three-way interaction effect of construal level, donation size, and emoticons was significant $(F=3.229, p=0.074)$. The contrast analysis showed that when the emoticons were presented, participants perceived higher benefits as the donation size increased regardless of their construal level (see Table 6 and Figure 4). In other words, participants primed with high-level construal (small size: 4.37 vs. large size: $5.41 ; F=4.350, p<0.05$ ) as well as those primed with low-level construal (small size: 4.23 vs. large size: $5.43 ; F=5.840, p<0.05$ ) perceived higher benefits as the donation size increased.

Table 6. Study 2 Results: means and standard deviations.

\begin{tabular}{|c|c|c|c|c|c|c|}
\hline Emoticons & $\begin{array}{l}\text { Construal } \\
\text { Level }\end{array}$ & $\begin{array}{l}\text { Donation } \\
\text { Size }\end{array}$ & $\begin{array}{l}\text { Perceived } \\
\text { Benefits }\end{array}$ & $\begin{array}{c}\text { Perceived } \\
\text { Monetary Sacrifice }\end{array}$ & $\begin{array}{l}\text { Product } \\
\text { Attitudes }\end{array}$ & $\begin{array}{l}\text { Participation } \\
\text { Intentions }\end{array}$ \\
\hline \multirow{4}{*}{ Emoticons } & \multirow{2}{*}{ High } & Small & $4.37(1.78)$ & $4.19(1.36)$ & $4.80(1.44)$ & 4.89 (1.46) \\
\hline & & Large & $5.41(1.01)$ & $4.23(1.59)$ & $5.65(0.96)$ & $5.74(0.87)$ \\
\hline & \multirow{2}{*}{ Low } & Small & $4.23(1.99)$ & $4.24(1.41)$ & 4.67 (1.67) & $4.77(1.66)$ \\
\hline & & Large & $5.43(1.38)$ & $4.67(1.23)$ & $5.73(0.95)$ & $5.48(1.01)$ \\
\hline \multirow{4}{*}{$\begin{array}{c}\text { No } \\
\text { emoticons }\end{array}$} & \multirow{2}{*}{ High } & Small & 4.17 (1.68) & $4.30(1.60)$ & $4.69(1.25)$ & $4.61(1.21)$ \\
\hline & & Large & $5.56(0.92)$ & $3.68(1.62)$ & $5.49(0.82)$ & $5.42(0.74)$ \\
\hline & \multirow{2}{*}{ Low } & Small & 4.60 (1.99) & $3.74(1.90)$ & $5.35(1.24)$ & $5.44(1.30)$ \\
\hline & & Large & 4.35 (1.99) & $5.30(1.85)$ & $4.58(1.89)$ & $4.48(2.04)$ \\
\hline
\end{tabular}

Note: The numbers in parentheses represent standard deviations.

However, when the emoticons were not presented, perceived benefits of participants varied according to construal level and donation size. More specifically, participants primed with higher construal level were more likely to perceive benefits of CRM in the large donation size condition $(\mathrm{M}=5.56)$ than in the small donation size condition $(\mathrm{M}=4.17 ; F=7.940, p<0.01)$, whereas among those primed with lower construal level, there were no significant differences in perceived benefits according to donation size $(F=0.244, p>0.1)$. This means that as predicted, the interaction effect of donation size and construal level was significant only when the emoticons were not presented. 


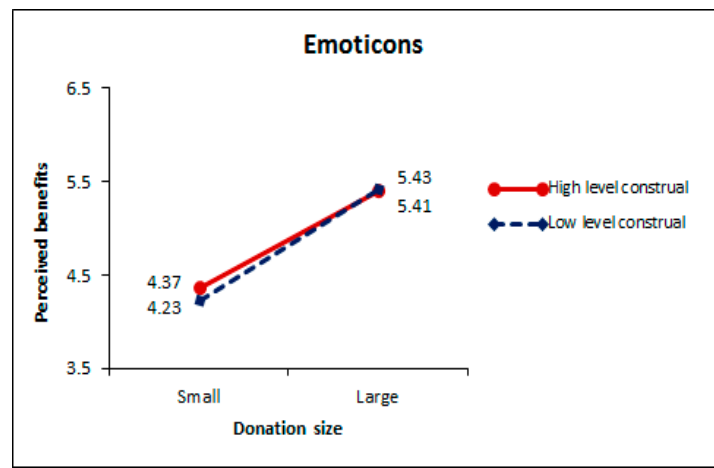

(a)

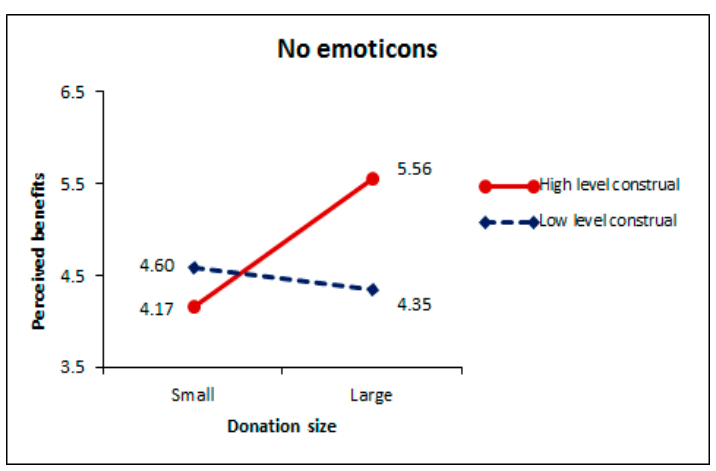

(b)

Figure 4. Interaction effects on perceived benefits: (a) emoticons condition and (b) no emoticons condition.

\subsubsection{Perceived Monetary Sacrifice}

The ANOVA results for perceived monetary sacrifice showed that the main effects of donation size, construal level, and emoticons were not significant (all, $p>0.1$ ). As predicted, however, the three-way interaction was significant $(F=4.835, p<0.05)$. The contrast analysis showed that when the emoticons were presented, the perceived monetary sacrifice of participants was not affected by donation size and construal level (all, $p>0.1$ ) (see Table 6 and Figure 5).

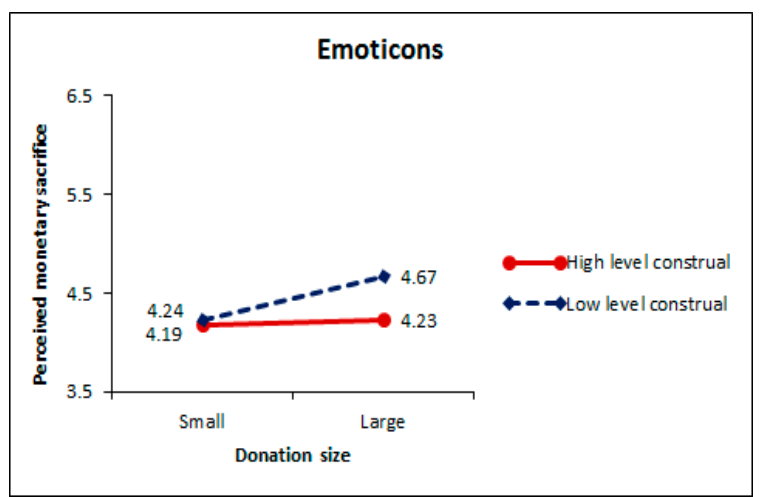

(a)

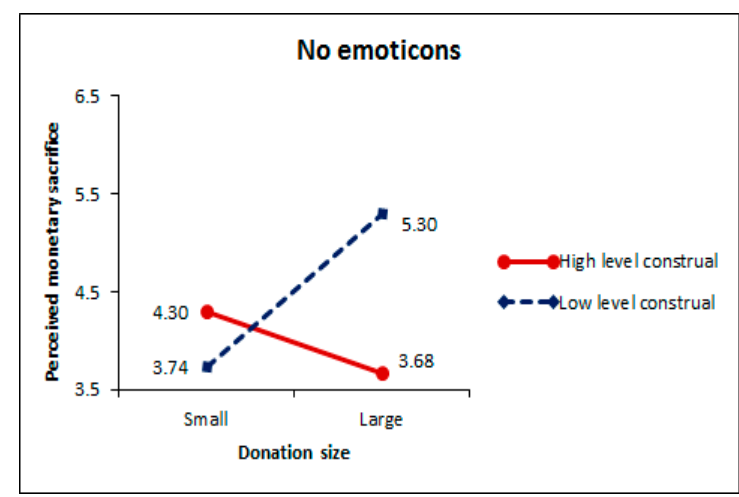

(b)

Figure 5. Interaction effects on perceived monetary sacrifice: (a) emoticons condition and (b) no emoticons condition.

However, when the emoticons were not presented, among participants primed with higher construal level, there were no significant differences in perceived monetary sacrifice according to donation size (small size: 4.30 vs. large size: $3.68 ; F=.1 .660, p>0.1$ ). Conversely, those primed with a lower construal level were more likely to perceive monetary sacrifice in the large donation size condition $(M=5.30)$ than in the small donation size condition $(\mathrm{M}=3.74 ; F=10.013, p<0.01)$. This means that the interaction effect of donation size and construal level on perceived monetary sacrifice was significant only when the emoticons were not presented.

\subsubsection{Product Attitudes}

The ANOVA results for product attitudes revealed the main effect of donation size $(F=5.748$, $p<0.05)$, showing that participants had more positive product attitudes when the size of donation was large $(M=5.37)$ than when the size was small $(M=4.87)$. The main effects of construal level and emoticons were not significant (all, $p>0.1$ ). More importantly, the three-way interaction effect on product attitudes was significant $(F=4.835, p<0.05)$. The results of contrast analysis showed 
that when the emoticons were presented, participants' product attitudes were more positive as the donation size increased regardless of their construal level (see Table 6 and Figure 6). In other words, participants primed with high-level construal (small size: 4.80 vs. large size: $5.73 ; F=4.477, p<0.05$ ) as well as those primed with low-level construal (small size: 4.67 vs. large size: $5.76 ; F=5.840, p<0.05$ ) had positive attitudes toward the product as the donation size increased.

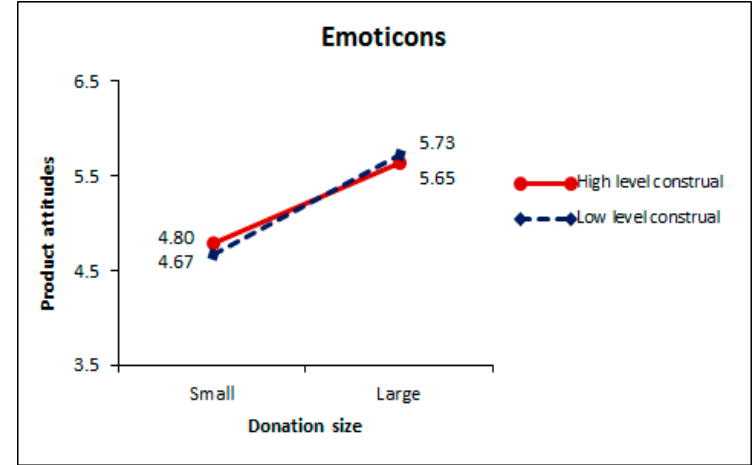

(a)

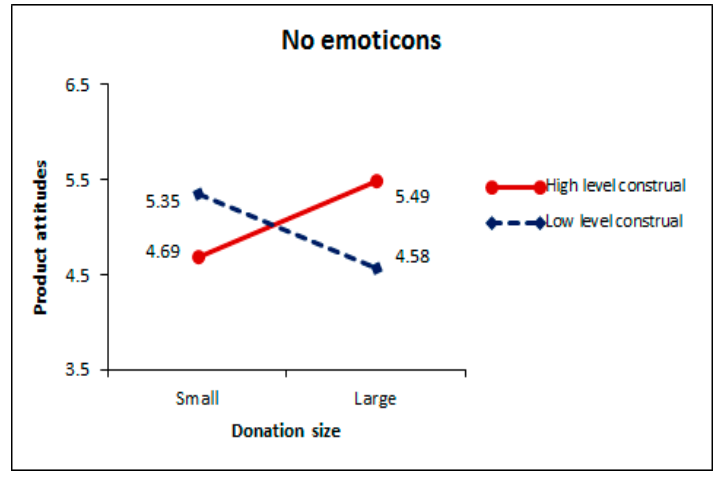

(b)

Figure 6. Interaction effects on product attitudes: (a) emoticons condition and (b) no emoticons condition.

However, when the emoticons were not presented, participants' attitudes toward the product varied according to construal level and donation size. More specifically, participants primed with higher construal level had more positive product attitudes in the large donation size condition $(\mathrm{M}=5.49)$ than in the small donation size condition $(\mathrm{M}=4.69 ; F=4.013, p<0.05)$. Conversely, participants primed with lower construal level had more positive attitudes in the small donation size condition $(\mathrm{M}=5.35)$ than in the large donation size condition $(\mathrm{M}=4.58 ; F=3.504, p=0.063)$. This means that, as predicted, the interaction effect of construal level and donation size on the product attitudes was significant only when the emoticons were not presented. Therefore, H5a was supported.

\subsubsection{Participation Intentions}

The ANOVA results for participation intentions revealed a marginally significant main effect of donation size $(F=2.892, p=0.091)$, showing that participants had more positive participation intentions when the size was large $(M=5.29)$ than when it was small $(M=4.92)$. The main effects of construal level and emoticons were not significant (all, $p>0.1$ ). Moreover, the three-way interaction was significant $(F=3.973, p<0.05)$. The contrast analysis showed that when the emoticons were presented, participants' participation intentions toward CRM were more positive as the donation size increased regardless of their construal level (see Table 6 and Figure 7). In other words, participants primed with high-level construal (small size: 4.89 vs. large size: $5.74 ; F=4.279, p<0.05$ ) as well as those primed with low-level construal (small size: 4.77 vs. large size: $5.48 ; F=3.033, p=0.083$ ) had positive intentions toward CRM participation as the donation size increased.

However, when the emoticons were not presented, participants' participation intentions varied according to donation size and construal level. Specifically, participation intentions of participants primed with a higher construal level were more positive in the large donation size condition $(\mathrm{M}=5.42)$ than in the small donation size condition $(\mathrm{M}=4.61 ; F=3.986, p<0.05)$. Conversely, participation intentions of those primed with lower construal level were more positive in the small donation size condition ( $M=5.33)$ than in the large donation size condition $(M=4.48 ; F=5.316, p<0.05)$. This means that the interaction effect of construal level and donation size on the participation intentions was significant only when the emoticons were not presented. Therefore, H5b was supported. 


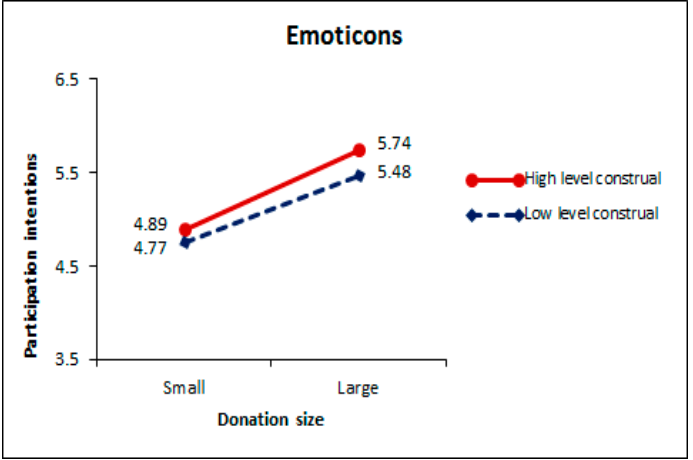

(a)

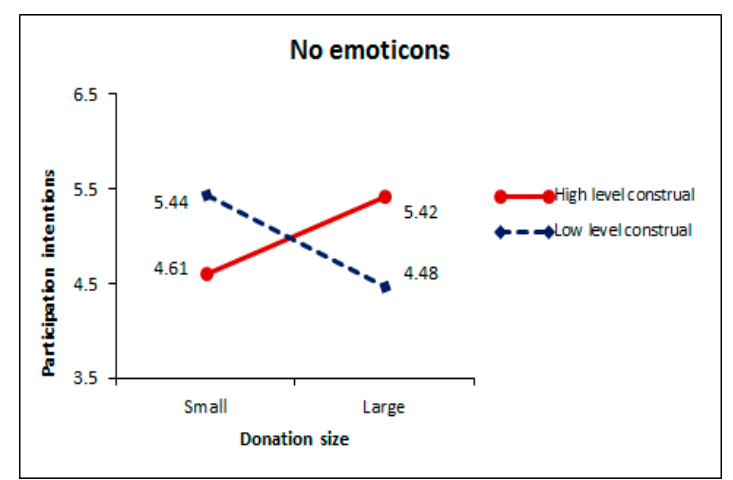

$(\mathbf{b})$

Figure 7. Interaction effects on participation intentions: (a) emoticons condition and (b) no emoticons condition.

\subsubsection{Mediation Analysis}

We run mediation analyses (model 6 in PROCESS macro) [78] using a bootstrapping analysis with 10,000 resamples [79] (see Table 7).

Table 7. Mediation analysis results (Study 2).

\begin{tabular}{|c|c|c|c|c|}
\hline \multicolumn{5}{|c|}{ Emoticons \& High-Level Construal } \\
\hline IV & MV 1 & MV 2 & DV & $95 \%$ CI \\
\hline \multirow[b]{2}{*}{ Donation size } & Perceived benefits & \multirow{2}{*}{ Product attitudes } & \multirow{2}{*}{$\begin{array}{l}\text { Participation } \\
\text { intentions }\end{array}$} & $0.04 \sim 0.73$ \\
\hline & $\begin{array}{c}\text { Perceived } \\
\text { monetary sacrifice }\end{array}$ & & & $-0.16 \sim 0.34$ \\
\hline \multicolumn{5}{|c|}{ Emoticons \& Low-Level Construal } \\
\hline \multirow[b]{2}{*}{ Donation size } & Perceived benefits & \multirow[b]{2}{*}{ Product attitudes } & \multirow{2}{*}{$\begin{array}{l}\text { Participation } \\
\text { intentions }\end{array}$} & $0.11 \sim 0.92$ \\
\hline & $\begin{array}{c}\text { Perceived } \\
\text { monetary sacrifice }\end{array}$ & & & $-0.07 \sim 0.34$ \\
\hline \multicolumn{5}{|c|}{ No Emoticons \& High-Level Construal } \\
\hline IV & MV 1 & MV 2 & DV & $95 \% \mathrm{CI}$ \\
\hline \multirow{2}{*}{ Donation size } & Perceived benefits & \multirow{2}{*}{ Product attitudes } & \multirow{2}{*}{$\begin{array}{l}\text { Participation } \\
\text { intentions }\end{array}$} & $0.17 \sim 1.04$ \\
\hline & $\begin{array}{c}\text { Perceived } \\
\text { monetary sacrifice }\end{array}$ & & & $-0.50 \sim 0.04$ \\
\hline \multicolumn{5}{|c|}{ No Emoticons \& Low-Level Construal } \\
\hline \multirow[b]{2}{*}{ Donation size } & Perceived benefits & \multirow[b]{2}{*}{ Product attitudes } & \multirow{2}{*}{$\begin{array}{l}\text { Participation } \\
\text { intentions }\end{array}$} & $-0.69 \sim 0.30$ \\
\hline & $\begin{array}{c}\text { Perceived } \\
\text { monetary sacrifice }\end{array}$ & & & $-1.11 \sim-0.07$ \\
\hline
\end{tabular}

Note: IV = independent variable; MV 1 = first mediate variables; MV 2 = second mediate variable; $\mathrm{DV}=$ dependent variable.

First, in the emoticons and high-level construal condition, a significant indirect effect via perceived benefits (donation size $\rightarrow$ perceived benefits $\rightarrow$ product attitudes $\rightarrow$ participation intentions) emerged (indirect effect $=26,95 \%$ CI: 0.04 0.73), whereas the indirect effect via perceived monetary sacrifice (donation size $\rightarrow$ perceived monetary sacrifice $\rightarrow$ product attitudes $\rightarrow$ participation intentions) was not significant (indirect effect $=-0.01,95 \% \mathrm{CI}:-0.16 \sim 0.34$ ).

Second, in the emoticons and low-level construal condition, a significant indirect effect via perceived benefits (donation size $\rightarrow$ perceived benefits $\rightarrow$ product attitudes $\rightarrow$ participation intentions) emerged (indirect effect $=41,95 \%$ CI: 0.11 0.92), whereas the indirect effect via perceived monetary 
sacrifice (donation size $\rightarrow$ perceived monetary sacrifice $\rightarrow$ product attitudes $\rightarrow$ participation intentions) was not significant (indirect effect $=0.04,95 \%$ CI: $-0.07 \sim 0.34$ ).

This implies that when the emoticons were presented, consumers were more likely to perceive the benefits rather than monetary sacrifice as the donation size increased regardless of their construal level, leading to positive product attitudes and intentions to participate in CRM.

Third, in the no emoticons and high-level construal condition, a significant indirect effect via perceived benefits (donation size $\rightarrow$ perceived benefits $\rightarrow$ product attitudes $\rightarrow$ participation intentions) emerged (indirect effect $=47,95 \%$ CI: 0.17 1.04), whereas the indirect effect via perceived monetary sacrifice (donation size $\rightarrow$ perceived monetary sacrifice $\rightarrow$ product attitudes $\rightarrow$ participation intentions) was not significant (indirect effect $=-0.14,95 \% \mathrm{CI}:-0.50 \sim 0.04$ ).

Finally, in the no emoticons and low-level construal condition, the indirect effect via perceived benefits (donation size $\rightarrow$ perceived benefits $\rightarrow$ product attitudes $\rightarrow$ participation intentions) was not significant (indirect effect $=-0.09,95 \% \mathrm{CI}:-0.69 \sim 0.30$ ), whereas a significant indirect effect via perceived monetary sacrifice (donation size $\rightarrow$ perceived monetary sacrifice $\rightarrow$ product attitudes $\rightarrow$ participation intentions) emerged (indirect effect $=-0.41,95 \%$ CI: $-1.11 \sim-0.07$ ).

This implies that when the emoticons were not presented, consumers at higher construal level (lower construal level) are more likely to perceive benefits (monetary sacrifice) rather than monetary sacrifice (benefits) as the size of the donation increases, leading to positive (negative) product attitudes and CRM participation intentions.

\section{Discussion and Conclusions}

This study aimed to assess the effects of donation size, construal level, and emoticons on consumers' response to CRM. The results of this study are summarized as follows. First, the influence of donation size varied depending on construal level. Among consumers with a higher construal level, the larger the donation size, the higher were the perceived benefits and the more positive were the product attitudes and intention to participate. However, among consumers with a lower construal level, the larger the donation size, the higher was the perceived monetary sacrifice and the more negative were the product attitudes and intention to participate. These results indicate that the influence of donation size is determined by perceived benefits and perceived monetary sacrifice according to construal level. Furthermore, the results of Study 2 showed the boundary condition of the interaction effects between donation size and construal level. That is, in Study 2, it is confirmed that when emoticons were presented, the interaction effect of donation size and construal level is attenuated. In the condition that emoticons were presented, consumers were more likely to perceive benefits of CRM more positively as the donation size increased, regardless of their construal level. These results showed that all of our hypotheses (H1 H5) were supported.

This study provides several implications for academics. First, previous studies related to donation size have shown both positive $[22,34,42-44]$ and negative effects $[11,45]$ of donation size on consumer responses. Moreover, they have failed to provide a clear mechanism for the influence of donation size on consumer responses. This study showed that consumer responses to donation size depend on their perceived benefits and perceived monetary sacrifice, confirming that perceived benefits and monetary sacrifice vary according to construal level. In conclusion, this study has contributed to the research related to the CRM field and donation size. It has also contributed to the expansion of research related to donation size by combining different research domains including donation size and construal level.

Furthermore, this study has suggested a way (using emoticons) to lower consumers' perceptions of monetary sacrifice that donation size may affect negatively. This study has shown that lowering consumers' perceptions of monetary sacrifice can increase their intention to participate, and emoticons, which were not interested in previous CRM research, play a role in lowering the perception of monetary sacrifice. Previous studies related to emoticons have focused on identifying the positive effects of emoticons on audience understanding and acceptance of message [59-61], service satisfaction, and behavioral intention [57]. However, this study provides more prominent and differential academic 
implications in that the presentation of emoticons in messages lowers consumers' perceptions of the importance of money, thereby enhancing their intention to participate.

This study provides the following practical implications. Based on previous studies, consumers might think that, as the size of the donation offered by a company increases, the benefits provided to others increase, and so they feel more warmth; however, they might also perceive that their financial sacrifice is increasing. From the perspective of a company trying to improve product attitudes and purchase intention by implementing CRM, the finding that the donation size is not always received positively and can even have a negative effect, poses a risk. In this regard, this study suggests the criterion for determining the size of the donation by explaining the mechanism of how consumers process donation-related information, which is not explained in previous studies. Specifically, the results of this study show that consumers with high-level construal have favorable responses as the donation increases because they perceive donation size as a benefit. However, consumers with low-level construal perceive donation size as monetary sacrifice, so they have negative responses as the donation increases. Therefore, companies should consider consumers' construal level in setting the donation size and find ways to activate the type of consumers' construal level in accordance with the situation. In this regard, CRM strategies using psychological distance can help a company set a donation size. Previous studies have suggested that construal level is related to psychological distance such as time, society, and space $[15,51]$. According to them, consumers have a higher construal level when they perceive specific objects or events to be more psychologically distant, while they have a lower construal level when they perceive objects or events to be closer. This means that donation size serves as a cue for benefits if donations are perceived by consumers to be temporally, spatially, and socially distant. In this case, the companies should set a large donation size so that consumers perceive that more benefits are offered to others. However, if donations are perceived by consumers to be temporally, spatially, and socially close, the donation size serves as a cue for monetary sacrifice. In this case, the companies should set a small donation size and should remind consumers that they can help others even with small amounts.

In addition, this study provides a way to minimize the perceived monetary sacrifice that negatively affects consumers' intention to participate in CRM. From a marketer's viewpoint, increasing the amount of donation implies an increase in a company's costs [11]. That is, donation size increases consumers' perceived costs resulting in negative outcomes, which means that the marketing strategy has failed even though the company increased its marketing budget. In this regard, this study shows that the emoticons included in the CRM messages reduce consumers' perceptions of monetary sacrifice and increase their participation intentions in CRM. This suggests that the use of emoticons that can be easily included in the CRM messages without additional costs prevents the risk of possible marketing failures and helps marketing managers achieve the desired results. Thus, the results of this study provide managerial implications to improve the effectiveness and efficiency of corporate CRM strategy.

Nevertheless, this study has limitations. First, the product categories used in this study are mineral water (Study 1) and coffee (Study 2), which are relatively inexpensive. In future studies, it is necessary to conduct experiments using products across various price ranges as stimuli. In the case of products with high price levels, consumers' perceptions of monetary sacrifice may be different from those in the case of low-price products, and consumers' level of involvement may be different. Therefore, it is necessary to examine the influence of the price range and involvement level according to the price range in future studies.

Second, future research also needs to examine the impact of product types. Previous studies have shown that consumers are more likely to experience negative feelings such as guilt or spending pain when buying hedonic products than utilitarian products $[17,80]$. It is also known that information related to CSR or CRM alleviates consumers' negative feelings about hedonic products [81]. This is because pro-social activities such as CSR and CRM justify consumers purchasing hedonic products. Therefore, in future studies, it is necessary to confirm whether the results of this study depend on the product type. 
Third, in this study, the donation size was presented in the form of ratio (\%). Prior studies have suggested that the presentation format of donation size may have different effects on consumer responses. In future research, therefore, it is necessary to confirm whether the results of this study depend on the presentation type (ratio vs. amount) of donation size.

Finally, this study focused on the influence of donation size among the various factors that may influence the success of CRM, but future studies need to examine the influence of other variables as well. For example, the characteristics of beneficiaries, NPOs, and CRM initiatives may affect psychological distance, and thus affect the results of this study; they may influence the perceived monetary sacrifice by affecting consumers' perceptions of authenticity in CRM. Therefore, in future research, it would be interesting to explore the effects of various factors on the relationship between donation size, perceived benefits, and monetary sacrifice.

Author Contributions: D.Y., J.-A.K., and S.-J.D. conceived the research idea and designed the research framework; D.Y. analyzed the data; J.-A.K. performed the experiments; S.-J.D. contributed materials and analysis tools; all authors wrote and reviewed the paper.

Funding: This research received no external funding.

Conflicts of Interest: The authors declare no conflicts of interest.

\section{Appendix A}

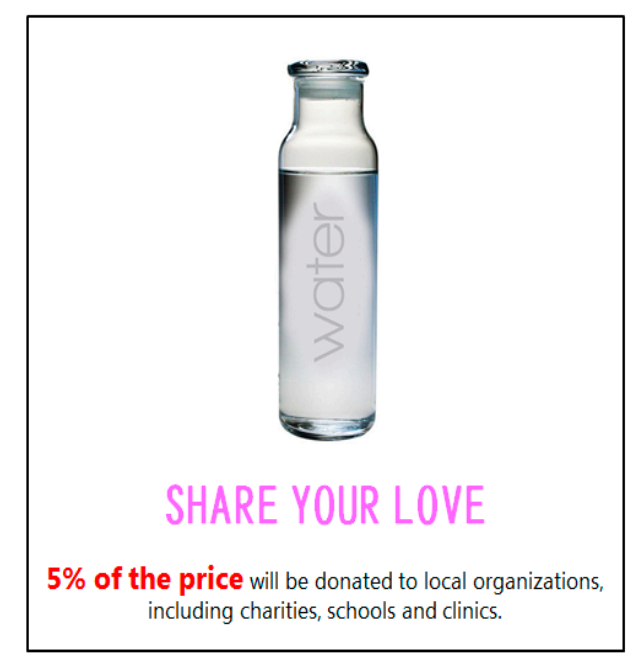

Figure A1. Example of stimuli from Study 1 (small donation size condition).

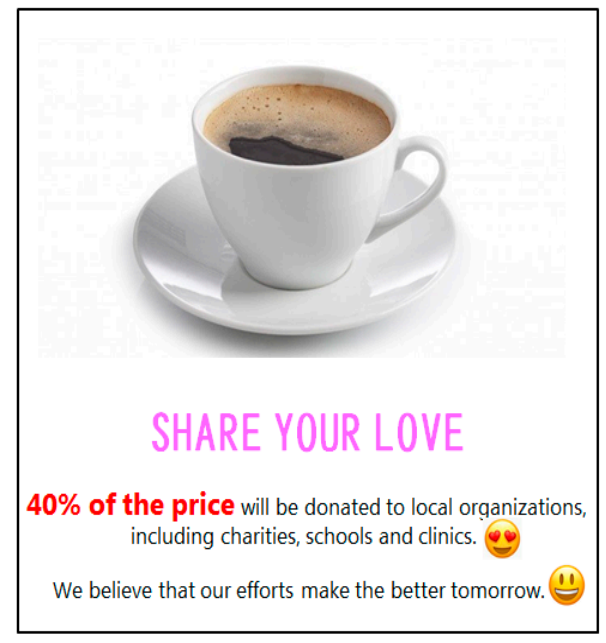

Figure A2. Example of stimuli from Study 2 (emoticons and large donation size condition). 


\section{References}

1. Yoo, D.; Lee, J. The effects of corporate social responsibility (CSR) fit and CSR consistency on company evaluation: The role of CSR support. Sustainability 2018, 10, 2956. [CrossRef]

2. Kotler, P.; Lee, N. Corporate Social Responsibility: Doing the Most for Your Company and for Your Cause; Wiley: Hoboken, NJ, USA, 2005.

3. Choi, S.; Lee, S.; Friske, W. The effects of featured advertising and package labeling on sustainability of cause-related marketing (CRM) products. Sustainability 2018, 10, 3011. [CrossRef]

4. Signs Point To Healthy Sponsorship Spending In 2018; IEG Sponsorship Report; IEG: Chicago, IL, USA, 2018.

5. Chernev, A.; Blair, S. Doing well by doing good: The benevolent halo of corporate social responsibility. J. Consum. Res. 2015, 41, 1412-1425. [CrossRef]

6. Pracejus, J.W.; Olsen, G.D.; Brown, N.R. On the prevalence and impact of vague quantifiers in the advertising of cause-related marketing (CRM). J. Advert. 2003, 32, 19-28. [CrossRef]

7. Brown, T.J.; Dacin, P.A. The company and the product: Corporate associations and consumer product responses. J. Mark. 1997, 61, 68-84. [CrossRef]

8. Koschate-Fischer, N.; Stefan, I.V.; Hoyer, W.D. Willingness to pay for cause-related marketing: The impact of donation amount and moderating effects. J. Mark. Res. 2012, 49, 910-927. [CrossRef]

9. Müller, S.S.; Fries, A.J.; Gedenk, K. How much to give? The effect of donation size on tactical and strategic success in cause-related marketing. Int. J. Res. Mark. 2014, 31, 178-191. [CrossRef]

10. Olsen, G.D.; Pracejus, J.W.; Brown, N.R. When profit equals price: Consumer confusion about donation amounts in cause-related marketing. J. Public Policy Mark. 2003, 22, 170-180. [CrossRef]

11. Strahilevitz, M. The effects of product type and donation magnitude on willingness to pay more for a charity-linked brand. J. Consum. Psychol. 1999, 8, 215-241. [CrossRef]

12. Human, D.; Terblanche, N.S. Who receives what? The influence of the donation magnitude and donation recipient in cause-related marketing. J. Nonprofit Public Sect. Mark. 2012, 24, 141-160. [CrossRef]

13. Folse, J.A.G.; Niedrich, R.W.; Grau, S.L. Cause-relating marketing: The effects of purchase quantity and firm donation amount on consumer inferences and participation intentions. J. Retail. 2010, 86, 295-309. [CrossRef]

14. Bornemann, T.; Homburg, C. Psychological distance and the dual role of price. J. Consum. Res. 2011, 38, 490-504. [CrossRef]

15. Trope, Y.; Liberman, N.; Wakslak, C. Construal levels and psychological distance: Effects on representation, prediction, evaluation, and behavior. J. Consum. Psychol. 2007, 17, 83-95. [CrossRef]

16. Lasaleta, J.D.; Sedikides, C.; Vohs, K.D. Nostalgia weakens the desire for money. J. Consum. Res. 2014, 41, 713-729. [CrossRef]

17. Xu, Q.; Zhou, Y.; Ye, M.; Zhou, X. Perceived social support reduces the pain of spending money. J. Consum. Psychol. 2015, 25, 219-230. [CrossRef]

18. Smith, N.C. Corporate social responsibility: Whether or how? Calif. Manag. Rev. 2003, 45, 52-76. [CrossRef]

19. Luo, X.; Bhattacharya, C.B. The debate over doing good: Corporate social performance, strategic marketing levers, and firm-idiosyncratic risk. J. Mark. 2009, 73, 198-213. [CrossRef]

20. McGuire, J.B.; Sundgren, A.; Schneeweis, T. Corporate social responsibility and firm financial performance. Acad. Manag. J. 1988, 31, 854-872.

21. Varadarajan, P.R.; Menon, A. Cause-related marketing: A coalignment of marketing strategy and corporate philanthropy. J. Mark. 1988, 52, 58-74. [CrossRef]

22. Dahl, D.W.; Lavack, A.M. Cause-related marketing: Impact of size of corporate donation and size of cause-related promotion on consumer perceptions and participation. In 1995 AMA Winter Educators' Conference: Marketing Theory and Applications; Amer Marketing Assn: Chicago, IL, USA, 1995; pp. $476-481$.

23. Burnett, J.J.; Wood, V.R. A proposed model of the donation decision process. Res. Consum. Behav. 1988, 3, $1-47$.

24. Smith, S.M.; Alcorn, D.S. Cause marketing: A new direction in the marketing of corporate responsibility. J. Consum. Mark. 1991, 8, 19-35. [CrossRef]

25. Polonsky, M.J.; Wood, G. Can the overcommercialization of cause-related marketing harm society? J. Macromark. 2001, 21, 8-22. [CrossRef]

26. Andrews, M.; Luo, X.; Fang, Z.; Aspara, J. Cause marketing effectiveness and the moderating role of price discounts. J. Mark. 2014, 78, 120-142. [CrossRef] 
27. Barone, M.J.; Norman, A.T.; Miyazaki, A.D. Consumer response to retailer use of cause-related marketing: Is more fit better? J. Retail. 2007, 83, 437-445. [CrossRef]

28. Coleman, J.T.; Peasley, M.C. Demonstrating a lack of brand/cause effects on point of sale donations. Manag. Mark. 2015, 10, 226-243. [CrossRef]

29. Lafferty, B.A.; Edmondson, D.R. A note on the role of cause type in cause-related marketing. J. Bus. Res. 2014, 67, 1455-1460. [CrossRef]

30. Strahilevitz, M.; Myers, J.G. Donations to charity as purchase incentives: How well they work may depend on what you are trying to sell. J. Consum. Res. 1998, 24, 434-446. [CrossRef]

31. Kim, J.; Kim, I. Entrepreneurial marketing and airline-cause sponsorship congruence: Passenger sponsorship response to US-based full-service airlines. Sustainability 2018, 10, 2359. [CrossRef]

32. Chen, R.; Su, S.; He, F. Does cause congruence affect how different corporate associations influence consumer responses to cause-related marketing? Aust. J. Manag. 2014, 39, 191-206. [CrossRef]

33. Berger, I.E.; Cunningham, P.H.; Kozinets, R.V. Consumer persuasion through cause-related advertising. ACR N. Am. Adv. 1999, 26, 491-497.

34. Moosmayer, D.C.; Fuljahn, A. Consumer perceptions of cause related marketing campaigns. J. Consum. Mark. 2010, 27, 543-549. [CrossRef]

35. Boenigk, S.; Schuchardt, V. Cause-related marketing campaigns with luxury firms: An experimental study of campaign characteristics, attitudes, and donations. Int. J. Nonprofit Volunt. Sect. Mark. 2013, 18, 101-121. [CrossRef]

36. Strahilevitz, M. The effects of prior impressions of a firm's ethics on the success of a cause-related marketing campaign: Do the good look better while the bad look worse? J. Nonprofit Public Sect. Mark. 2003, 11, 77-92. [CrossRef]

37. Wymer, W.; Samu, S. The influence of cause marketing associations on product and cause brand value. Int. J. Nonprofit Volunt. Sect. Mark. 2009, 14, 1-20. [CrossRef]

38. Ross, J.K.; Patterson, L.T.; Stutts, M.A. Consumer perceptions of organizations that use cause-related marketing. J. Acad. Mark. Sci. 1992, 20, 93-97. [CrossRef]

39. Barnes, N.G. Determinants of consumer participation in cause-related marketing campaigns. Am. Bus. Rev. 1992, 10, 21-24.

40. Zdravkovic, S.; Magnusson, P.; Stanley, S.M. Dimensions of fit between a brand and a social cause and their influence on attitudes. Int. J. Res. Mark. 2010, 27, 151-160. [CrossRef]

41. Grau, S.L.; Folse, J.A.G. Cause-related marketing (CRM): The influence of donation proximity and message-framing cues on the less-involved consumer. J. Advert. 2007, 36, 19-33. [CrossRef]

42. Holmes, J.H.; Kilbane, C.J. Cause-related marketing: Selected effects of price and charitable donations. J. Nonprofit Public Sect. Mark. 1993, 1, 67-84. [CrossRef]

43. Krishna, A. Can supporting a cause decrease donations and happiness? The cause marketing paradox. J. Consum. Psychol. 2011, 21, 338-345. [CrossRef]

44. Hajjat, M.M. Effect of cause-related marketing on attitudes and purchase intentions: The moderating role of cause involvement and donation size. J. Nonprofit Public Sect. Mark. 2003, 11, 93-109. [CrossRef]

45. Chang, C.-T.; Lee, Y.-K. The roles of product characteristics and framing effects in the effectiveness of cause-related marketing. ACR N. Am. Adv. 2008, 35, 780-781.

46. Liberman, N.; Trope, Y. The role of feasibility and desirability considerations in near and distant future decisions: A test of temporal construal theory. J. Personal. Soc. Psychol. 1998, 75, 5-18. [CrossRef]

47. Trope, Y.; Liberman, N. Temporal construal. Psychol. Rev. 2003, 110, 403-421. [CrossRef] [PubMed]

48. Liberman, N.; Trope, Y. The psychology of transcending the here and now. Science 2008, 322, 1201-1205. [CrossRef] [PubMed]

49. Sagristano, M.D.; Trope, Y.; Liberman, N. Time-dependent gambling: Odds now, money later. J. Exp. Psychol. Gen. 2002, 131, 364-376. [CrossRef] [PubMed]

50. Trope, Y.; Liberman, N. Construal-level theory of psychological distance. Psychol. Rev. 2010, 117, 440-463. [CrossRef] [PubMed]

51. Lermer, E.; Streicher, B.; Sachs, R.; Raue, M.; Frey, D. The effect of construal level on risk-taking. Eur. J. Soc. Psychol. 2015, 45, 99-109. [CrossRef]

52. Labroo, A.A.; Patrick, V.M. Providing a moment of respite: Why a positive mood helps seeing the big picture. J. Consum. Res. 2009, 35, 800-809. [CrossRef] 
53. Spassova, G.; Lee, A.Y. Looking into the future: A match between self-view and temporal distance. J. Consum. Res. 2013, 40, 159-171. [CrossRef]

54. Hansen, J.; Wänke, M. The abstractness of luxury. J. Econ. Psychol. 2011, 32, 789-796. [CrossRef]

55. Derks, D.; Bos, A.E.; Von Grumbkow, J. Emoticons in computer-mediated communication: Social motives and social context. Cyberpsychol. Behav. 2008, 11, 99-101. [CrossRef] [PubMed]

56. Huffaker, D.A.; Calvert, S.L. Gender, identity, and language use in teenage blogs. J. Comput. Mediat. Commun. 2005, 10, JCMC10211. [CrossRef]

57. Li, X.S.; Chan, K.W.; Kim, S. Service with emoticons: How customers interpret employee use of emoticons in online service encounters. J. Consum. Res. 2018. [CrossRef]

58. Xu, L.; Yi, C.; Xu, Y. Emotional expression online: The impact of task, relationship and personality perception on emoticon usage in instant messenger. In Proceedings of the 11th Pacific-Asia Conference on Information Systems, Auckland, New Zealand, 4-6 July 2007; p. 79.

59. Aldunate, N.; González-Ibáñez, R. An integrated review of emoticons in computer-mediated communication. Front. Psychol. 2017, 7, 2061. [CrossRef] [PubMed]

60. Lo, S.-K. The nonverbal communication functions of emoticons in computer-mediated communication. Cyberpsychol. Behav. 2008, 11, 595-597. [CrossRef] [PubMed]

61. Wang, W.; Zhao, Y.; Qiu, L.; Zhu, Y. Effects of emoticons on the acceptance of negative feedback in computer-mediated communication. J. Assoc. Inf. Syst. 2014, 15, 454-483. [CrossRef]

62. Abele, A.E.; Brack, S. Preference for other persons' traits is dependent on the kind of social relationship. Soc. Psychol. 2013, 44, 84-94. [CrossRef]

63. Williams, L.A.; Bartlett, M.Y. Warm thanks: Gratitude expression facilitates social affiliation in new relationships via perceived warmth. Emotion 2015, 15, 1-5. [CrossRef] [PubMed]

64. Lane, R.E. The Loss of Happiness in Market Democracies; Yale University Press: New Haven, CT, USA, 2000.

65. Vohs, K.D.; Mead, N.L.; Goode, M.R. The psychological consequences of money. Science 2006, 314, 1154-1156. [CrossRef] [PubMed]

66. Chaplin, L.N.; John, D.R. Growing up in a material world: Age differences in materialism in children and adolescents. J. Consum. Res. 2007, 34, 480-493. [CrossRef]

67. Pieters, R. Bidirectional dynamics of materialism and loneliness: Not just a vicious cycle. J. Consum. Res. 2013, 40, 615-631. [CrossRef]

68. Buhrmester, M.; Kwang, T.; Gosling, S.D. Amazon's Mechanical Turk: A new source of inexpensive, yet high-quality, data? Perspect. Psychol. Sci. 2011, 6, 3-5. [CrossRef] [PubMed]

69. Paolacci, G.; Chandler, J.; Ipeirotis, P.G. Running experiments on amazon mechanical turk. Judgm. Decis. Mak. 2010, 5, 411-419.

70. Cowan, K.; Kinley, T. Green spirit: Consumer empathies for green apparel. Int. J. Consum. Stud. 2014, 38, 493-499. [CrossRef]

71. Hair, J.; Black, W.; Babin, B.; Anderson, R. Multivariate Data Analysis; Prentice Hall: Upper Saddle River, NJ, USA, 2009.

72. Chang, C.T. To donate or not to donate? Product characteristics and framing effects of cause-related marketing on consumer purchase behavior. Psychol. Mark. 2008, 25, 1089-1110. [CrossRef]

73. Fujita, K.; Trope, Y.; Liberman, N.; Levin-Sagi, M. Construal levels and self-control. J. Personal. Soc. Psychol. 2006, 90, 351-367. [CrossRef] [PubMed]

74. Wang, J.; Hong, J.; Zhou, R. How long did I wait? The effect of construal levels on consumers' wait duration judgments. J. Consum. Res. 2017, 45, 169-184. [CrossRef]

75. Vallacher, R.R.; Wegner, D.M. Levels of personal agency: Individual variation in action identification. J. Pers. Soc. Psychol. 1989, 57, 660-671. [CrossRef]

76. Green, T.; Peloza, J. Finding the right shade of green: The effect of advertising appeal type on environmentally friendly consumption. J. Advert. 2014, 43, 128-141. [CrossRef]

77. Suri, R.; Monroe, K.B. The effects of time constraints on consumers' judgments of prices and products. J. Consum. Res. 2003, 30, 92-104. [CrossRef]

78. Preacher, K.J.; Hayes, A.F. Asymptotic and resampling strategies for assessing and comparing indirect effects in multiple mediator models. Behav. Res. Methods 2008, 40, 879-891. [CrossRef] [PubMed]

79. Zhao, X.; Lynch, J.G.; Chen, Q. Reconsidering Baron and Kenny: Myths and truths about mediation analysis. J. Consum. Res. 2010, 37, 197-206. [CrossRef] 
80. Kivetz, R.; Simonson, I. Earning the right to indulge: Effort as a determinant of customer preferences toward frequency program rewards. J. Mark. Res. 2002, 39, 155-170. [CrossRef]

81. Hagtvedt, H.; Patrick, V.M. Gilt and guilt: Should luxury and charity partner at the point of sale? J. Retail. 2016, 92, 56-64. [CrossRef] 